\title{
Growing Business Entrepreneurs And Enhancing The Competitiveness Of Community SME's Productsof Hendrosari Village, Menganti District, Gresik Regency
}

\author{
Author \\ Beni Dwi Komara (Orcid ID. 0000-0003-4952-5118), Heri Cahyo Bagus Setiawan (Orcid ID. 0000-0001-9983-8951), \\ Muhammad Ghufran Ramdhani (Orcid ID. 0000-0002-9983-8952), Ragillia (Orcid ID. 0000-0003-9983-8952).
}

\author{
Correspondence \\ Universitas Muhammadiyah Gresik. \\ benikomara@umg.ac.id, hericbs@umg.ac.id, danirambo89@gmail.com, putriragil1992@gmail.com
}

\begin{abstract}
:
Lontar Tourism Village, Hendrosari Village, Menganti Subdistrict, Gresik Regency is located in the range of $15 \mathrm{Km}$ from the center of Gresik. The locals are very creative by continuing their culinary innovations besides Legen and dawet siwalan to the grilled chicken menu as a companion. The community's huge interest in the typical culinary of Hendrosari Village is then continued with the development of the tourist village of Lontar Sewu Nature \& Culinary Tourism Village. There is a jogging track built to cross the palm plantations, a traditional culinary center of Gresik and a tourist attraction for game rides and a great place for selfies.

Physically, the development of the tourism village has been completed and began to operate, but there are still many stakeholders, especially the main activists of the Tourism Village and the community still need guidance as to how they are able to optimize the potential of the tourist village in their place through entrepreneurship. How to take the right steps so that the local wisdom of this tourism village is able to significantly strengthen the superiority of the product which is expected to be able to raise economic independence in the village of Hendrosari.

This problem then became the basis of the Community Partnership Program (PKM) in Hendrosari village. Through this program, the main activists of the Tourism Village consisting of Bumdes, PKK cadres, Karang Taruna cadres and the Tourism Village Activity Organizing Committee and the community will be given a briefing to foster entrepreneurial spirit enhancing the competitiveness of MSME products, the Lontar Tourism Village, Hendrosari Village, Menganti District, Gresik Regency .

The purpose of carrying out PKM activities are; 1 . Growing the entrepreneurial spirit of the community of Hendrosari village 2. Increasing the product competitiveness of the community of the village of Hendrosari. The method used is the lecture and discussion method, technology transfer and demonstration method.

Through coaching in the PKM program, it is expected that the main activists in the Tourism Village and the community will be able to foster an entrepreneurial spirit and be able to increase the competitiveness of the MSME products of the Lontar Tourism village community, Hendrosari Village, Menganti District, Gresik Regency.
\end{abstract}

Keywords: Entrepreneurship; Product competitiveness, SMEs and Tourism Villages

Received: 26 March 2020. Accepted: 04 August 2020

\section{Introduction}

Hendrosari Village in Menganti

District, Gresik. The village is bordered by

Benowo to the east and Boboh to the west.

In the village, lontar trees grow - only in the village. While in the surrounding villages, siwalan plants cannot grow as much as in Hendrosari. In terms of history and culture that supports the palm tree also has a strong position in the community. Hendrosari villagers believe, who used to plant are the trustees. Thanks to the trustees, these plants can grow in rows there. The guardians' habit of writing messages through palm leaves also supports this belief. Moreover, the Lontar Plant is indeed identical with the
Tuban, Lamongan and Coastal regions of the north coast of Java. But, Hendrosari is an anomaly. The village is far from the north coast of Java, but the Lontar Tree can grow and develop there. Maybe because of this long distance with the sea, the air from Hendrosari is different from the others.

Lontar plant in Hendrosari is estimated to grow more than 100 years. Evidenced by the number of plants that reach 7 meters. To be able to grow that high, it takes time that is not left. Palm trees begin to extract sap water that can be consumed, at least it takes 35 years to reap the rewards. This palm tree is difficult to climb because of its tall shape and small diameter, special 
skills are needed so as not to mature. There have been no fatalities from climbing this tree but there have been fallen and paralyzed and the average Lontar farmer has slightly curved legs in his old age because it has improved his climbing ability. Maybe because of passing, there are no more young people who are actively climbing the palm trees. Young people in Hendrosari prefer to work in factories or work outside the more promising villages. Minister of Youth and Sports (Menpora) Imam Nahrawi conveyed that Indonesia is not only short of entrepreneurs but also young entrepreneurs, If you compare the number of youth around 61 million while entrepreneurs are only 1.5 million. Ideally we have 20 million young entrepreneurs (Ispranoto, 2017). For this reason, it is necessary to increase the number of entrepreneurs, especially in the village of Hendrosari which has many business opportunities that can be developed. Therefore, real efforts need to be made so that the number of entrepreneurs continues to grow.At present in the village of Hendrosari, village development has been carried out into the Lontar Sewu Nature \& Culinary Tourism Village. In fact, a jogging track has been provided to traverse the palm plantations. Originally made from bamboo, now it is finished made of concrete on top of which is given wood to create a more natural atmosphere when crossing the Lontar garden. Visitors will be spoiled by seeing the beautiful view of palm trees lined up around the residents' verdant rice fields during the growing season. . The number of visitors reached 3,000 people which gave rise to market potential for the sale of local souvenirs, culinary products and so on. Serious efforts need to be made to foster entrepreneurial spirit in increasing the competitiveness of MSME products in the Lontar Tourism Village community, Hendrosari Village, Menganti District, Gresik Regency.

The existence of traditional traders and SMEs needs to be considered for their existence. In many places in Indonesia, SMEs and Traditional Traders have been unable to compete with traditional retail traders, making traditional traders and SMEs losing hope. Reconstruction of traditional traders is needed as a policy oriented to the people's economy to return to traditional markets and allow traditional traders to resell. Don't assume that people only become social objects of economy, politicians, politicians, and regional government at certain times such as regional and presidential elections (Komara, B.D. and Prasetya, A., 2019)

Physically the development of the tourism village has been completed, but there are still many parties involved in the village of Hendrosari who are the main activists of the Tourism Village and the community still needs guidance as to how they are able to optimize the potential of the tourist village in their place. How to take the right steps to be able to take advantage of this tourist village able to raise the reality of economic independence in the village of Hendrosari. If possible a good arrangement is not carried out, this potential will be widely used by people or other traders from outside the village of Hendrosari to sell. In the future, if there are more and more it will be difficult and potentially cause conflict. Formally a professional organization system needs to be built in the organization of SMEs and traditional traders known as the "Circle of Friends" and needs good coaching from the village government towards the UK and informal sector traders. (Prasetya, Agus, and Beni Dwi Komara.2019)

The following are the fields of business that have been running in the village of Hendrosari: 
Table1. Some Cullinary Village

\begin{tabular}{|c|c|c|}
\hline \multicolumn{2}{|c|}{ Industrial Name } & \multirow{2}{*}{$\begin{array}{l}\text { Production result } \\
\text { Legen }\end{array}$} \\
\hline 1. & $\begin{array}{l}\text { Legen Asli } \\
\text { Cak Lim }\end{array}$ & \\
\hline 2. & $\begin{array}{l}\text { Legen Asli } \\
\text { Pak Wito }\end{array}$ & Legen \\
\hline 3. & $\begin{array}{l}\text { Legen Asli } \\
\text { Pak Juli }\end{array}$ & Legen \\
\hline 4. & Rumah & Legen \\
\hline & $\begin{array}{l}\text { Makan Sari } \\
\text { Legen } \\
\text { Siwalan H. } \\
\text { Ponnadhir }\end{array}$ & Legen \\
\hline 6. & $\begin{array}{l}\text { RM Lesehan Berkah } \\
\mathbf{n}_{\sim \sim \mathbf{L}} \text { : }\end{array}$ & Grilled Chicken \\
\hline 8. & Rumah Makan Pak & Grilled chicken \\
\hline 9. & $\begin{array}{l}\text { Wito } \\
\text { Depot Ayam } \\
\text { Panggang Ibu Hj. }\end{array}$ & Grilled chicken \\
\hline 10. & $\begin{array}{l}\text { Ruminnah } \\
\text { RM Dua Siwalan } \\
\text { Cak Pa'i }\end{array}$ & Grilled chicken \\
\hline 11. & Warung RD & Fried Eel, Fried Catfish \\
\hline & $\begin{array}{l}\text { Pecel Belut Pak } \\
\text { Hari }\end{array}$ & Fried Eel, Fried Catfish \\
\hline
\end{tabular}

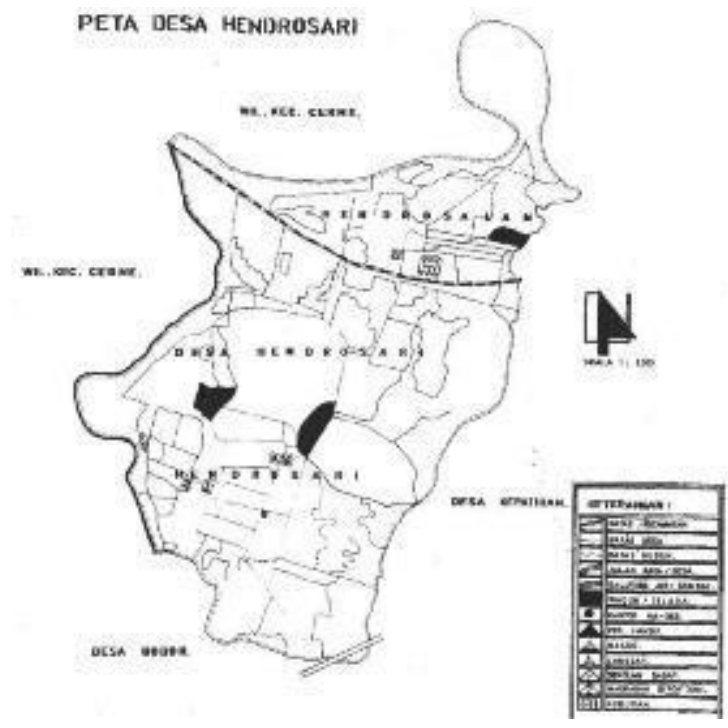

Figure 1. Location Map of Hendrosari Vilage

\section{Method}

The implementation method is the description of the stages inapplying the solutions that have been of fered to over come the edupreneur Lontar Sewu problemin Hendrosari Village, as follows:The method of implementation in helping the community Foster Entrepreneurial Souls and Improve the Competitiveness of Umkm Products Community Lontar Tourism Village,
Hendrosari Village, Menganti District, Gresik Regency, is conducted using lecture and discussion methods. The implementation method in assisting the community or target group in helping entrepreneurial abilities is carried out by using the Entrepreneurship Capacity Building (ECB) model, namely by providing insight into skills, opportunities to try and foster entrepreneurial spirit and improve the competitiveness of the umkm product community in Lontar Tourism Village, Hendrosari Village Menganti, Gresik Regency

\section{Results and Discussion}

As a result, the main activists of the Hendrosari Village and the community were able to empower the economy by fostering an entrepreneurial spirit and increasing the competitiveness of the product tourism village community based on local wisdom. Local wisdom that can be instilled in the social behavior of entrepreneurs among them is by implementing a mutual cooperation business strategy and a business selection attitude that benefits the community. Whereas in the aspect of strengthening product excellence, local wisdom arises in product design both brand, packaging \& function and the application of cultural preservation when introducing the local brands they have to the public.

\section{-PKM Program Activities}

\section{Location of Activities orPartner \\ Activities}

The activities or activities of partners so far have been carried out in Hendrosari village Menganti District area of Gresik Regency.

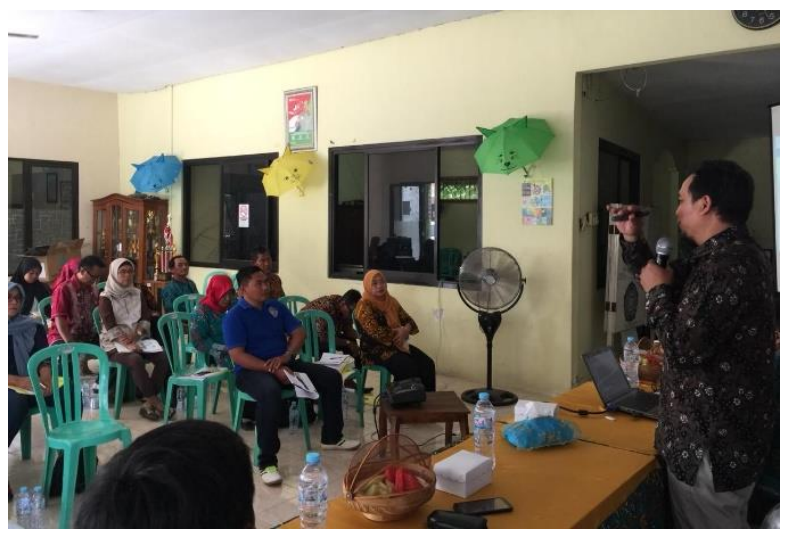




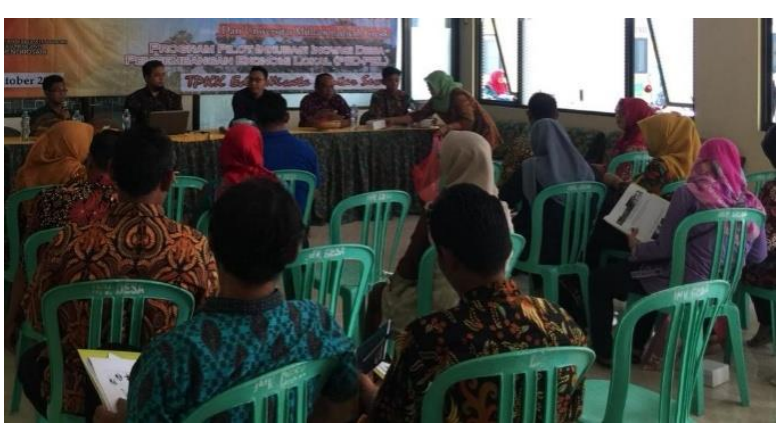

Figure 2. The Community Foster Entrepreneurial Souls

Together with partners, the servants carried out several activities including:

a. Seminar, which is a meeting conducted by a group of people with the aim to discuss a particular topic and find solutions to problems by way of question and answer interaction. The goal is to foster entrepreneurial spirit and improve the competitiveness of the umkm product community in Lontar Tourism Village

b. Workshop; that is, a single educational program, to teach or introduce each participant with practical, technical, or ideas that can be used in their work in their daily lives.

From the results of the activity, it can be concluded that fostering an entrepreneurial spirit and increasing the competitiveness of the ummah tourism village community based on local wisdom. They have not been able to carry out business with the optimization of existing potential.

Furthermore, Local wisdom that can be instilled in the social behavior of entrepreneurs among them is by implementing a mutual cooperation business strategy and a business selection attitude that benefits the community. Whereas in the aspect of strengthening product excellence, local wisdom arises in product design both brand, packaging \& function and the application of cultural preservation when introducing the local brands they have to the public.

The funds disbursed reached Rp.1,3 billion from the Ministry of Villages, Development of Disadvantaged Regions, and Transmigration of the Republic of Indonesia. This is coupled with assistance funds from the village budget of Rp.300 million.
1. Condition of Lontar Sewu Tourist Village

Theestatelocated in front of Hendrosari lakewith an area of $2.411 \mathrm{~m}^{2}$ on the land of the Gresik Government.

In addition, a variety of cheap tours can be enjoyed by visitors ranging from, water tourism, children's playgrounds, unique home gardens, palm selfie spots, legen water harvesting, culinary snacks, and family leisure area facilities.

Hendrosari Tourism Village also offers culinary specials of grilled chicken, grilled fish, and legen drinks that can be enjoyed by visitors with family during the weekend holidays. Hendrosari village is located on Jalan Hendrosari, Menganti District, Gresik Regency. Various restaurants and depots and food stalls typical of Hendrosari become the choice of visitors who want culinary with family.

2. Growing An Entrepreneurial Spirit And Increasing The Competitiveness Of The Product Tourism Village Community Based On Local Wisdom

Thefollowing is a description that will be implemented;

a) The success of owning a business is generated by a strong interest \& motivation to own the business, the ability to make a business plan, working hard to improve the ability to start in business, knowledge \& skills supported by skills training and assistance. (Komara, Beni Dwi, and Heri Cahyo Bagus Setiawan, 2020)

b) Companies that can survive in business competition, must use strategies that are oriented towards innovative and efficient values by looking at the resources and capabilities of a holistic company. When giant coffee industry companies use red ocean strategy in market competition, small and medium-sized coffee industry companies (MSMEs) such as Santri Coffee Industry in this study take alternative blue ocean strategies into strategy choices. Choice of strategies that focus on 
differentiation. (Setiawan, Heri Cahyo Bagus, and Beni Dwi Komara, 2020)

c) Strengthening product excellence based on local wisdom, namely by implementing a mutual cooperation business strategy and a business selection attitude that benefits the community. While in the aspect of strengthening product excellence, local wisdom is the mainstay that appears in good product design, packaging and design. (Samodra, 2018).

\section{Site Visit "Discussion fosters business} capabilities and competitive products in Hendrosari Tourism Village".

During the visit to our location, the PKM team was shown one by one the village community business units around the village area including the handicraft business, grilled chicken, and Siwalan ice dawet drinks, as well as showing the sights of the Lotar sewu tourist attractions.

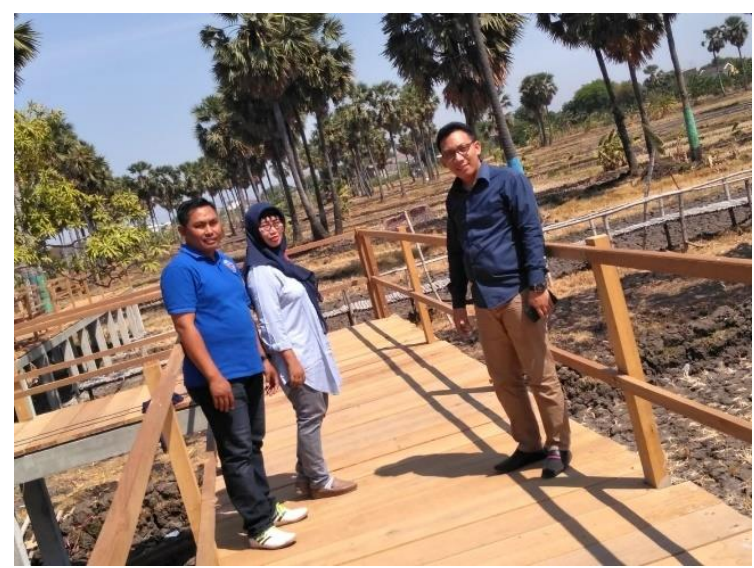

Figure 3. Site Visit \& Discussion

\section{Conclusion}

Some conclusions that the author can conveyare:

1. Seriously fostering young people who want to be entrepreneurial in order to take advantage of the potential of Tourism Village which has a large enough visitor market and promises a sustainable business.

2. Periodically conducting training and training for entrepreneurs to make products that can compete

3. To develop local wisdom-based products in mutual cooperation to jointly build attractive brands, designs, packaging and have official licenses.

4. Ensuring SMEs and traditional traders use strategies that are oriented towards innovative and efficient values by looking at the company's resources and capabilities holistically.

5. Creating a community that fosters traditional traders and SMEs in the Hendrosari tourism village so that it is easier to foster and facilitate the economic improvement of the Hendrosari village community.

\section{References}

Komara, BD. 2019. Manajemen Diri. UMG Press, Gresik

Komara, B.D. and Prasetya, A., 2019. Konstruksi Sosial pada Pedagang Tradisional dalam Menghadapi Era Kompetisi Perdagangan Bebas. Jurnal Riset Entrepreneurship, 2(1), pp.1-8.

Komara, Beni Dwi, and Heri Cahyo Bagus Setiawan. 2020. "Inkubator Bisnis Sebagai Pendorong Tumbuhnya Wirausaha Muda: Studi Tentang Suksesi Kewirausahaan Mahasiswa Universitas Muhammadiyah Gresik." Jurnal Riset Entrepreneurship 3.1 (2020): 33-39.

Kurniawan, A. 2018. Start, Run And Grow BUMDesa, UMG Press, Gresik

Kurniawan, A., Farida, Y. 2019. Alasan Warga Daerah Agraris Menjalankan Bisnis. Jurnal Riset Entrepreneurship, 2(1), 27-32.

Prasetya, Agus, and Beni Dwi Komara. 2019.

"Perlawanan Pedagang Kaki Lima Terhadap Kebijakan Relokasi Pemerintah Daerah". Jurnal Riset Entrepreneurship 2.2 (2019): 1-7.

Profil Desa Hendrosari. Available from: https://hendrosaridesaid.wordpress.co m/potensi-desa/Diakses 27 Oktober 2019.

Tri Ispranoto - detikNews. 2017. Menpora: Indonesia Kekurangan Pengusaha Muda. dapat diakses di https://news.detik.com/berita-jawa- 
barat/d-3576044/menpora-indonesia-

kekurangan-pengusaha-muda

Samodro, Samodro. 2018. "Upaya

Meningkatkan Daya Saing Ekspor

Produk Umkm Makanan Dan

Minuman Melalui Pengembangan

Usaha Dengan Berbasis Pada

Kearifan Lokal Di Indonesia."

Prosiding Sembadha 1.1 (2018): 130-

137.

Setiawan, Heri Cahyo Bagus, and Beni Dwi

Komara. 2020. "The Alternative Blue

Ocean Strategy: Bagaimana Strategi

Perusahaan Industri Kopi Santri

Dalam Menghadapi Persaingan

Bisnis?." Jurnal Riset

Entrepreneurship 3.1 (2020): 26-32. 